\title{
ВПЛИВ ЦІННІСНИХ ОРІЕНТАЦІЙ НА ФОРМУВАННЯ УЯВЛЕНЬ ПРО ПСИХОЛОГІЧНЕ БЛАГОПОЛУЧЧЯ У СТУДЕНТСЬКОЇ МОЛОДІ
}

У статті здійснено теоретичний аналіз проблеми, проаналізовано різні підходи до обтрунтування явища психологічного благополуччя (його складові й рівні прояву) та висвітлено теоретико-методологічні аспекти формування психологічного благополуччя особистості для повноцінного функціонування 6 соціумі. Розкрито сутність взаємозв'язку психологічного благополуччя з ціннісними оріснтаціями особистості. Емпіричним иляхом виявлено вплив ціннісних орієнтацій на формування уявлень про психологічне благополуччя у студентської молодi.

Ключові слова: цุіннісні орієнтащії, психологічне благополуччя, особистісне самоздійснення, студентська молодь.

Постановка проблеми. Ціннісні орієнтири розглядаються як одна зі складових психологічного благополуччя особистості, що визначає способи особистісного самоздійснення. У цьому контексті категоріям цінності і психологічного благополуччя особистості належить провідне місце, адже саме завдяки їх взаємозв'язку, стає можливим розв'язання деякої низки психолого-педагогічних проблем як теоретичного, так і практичного порядку, особливо тих проблем, які стосуються процесу самореалізації та самотворення особистості упродовж одного з важливих онтогенетичних етапів життєвого шляху, яким є етап навчання у вищому навчальному закладі (студентський вік). Вирізняючись наявністю кризових проявів, даний віковий період визначається складністю i схильністю до протиріч, а тому потребує мобілізаційності щодо власних ресурсів.

Психологічне благополуччя особистості студента у науковій площині сучасних досліджень трактується як інтегральна сукупність психологічних його властивостей, зумовлена чинниками зовнішнього й внутрішнього походження зі спрямованістю на позитивне його функціонування в процесі професійного становлення. Особливо важливим видається процес виявлення впливових на подальше життя чинників психологічного благополуччя, та тих умов і критеріїв, які стануть найбільш важливими для формування психологічного благополуччя для особистості в майбутньому.

Відповідно, все вище означене, лише підкреслює необхідність подальшого більш розгорнутого вивчення проблеми психологічного благополуччя у зв'язку з ціннісними орієнтаціями, 3 метою вироблення реалізаційних шляхів і способів становлення особистості, розкриття ії потенційних можливостей, конструктивності по відношенню до дійсності, окреслення позитивного підходу до вирішення життєвих проблем.

Аналіз останніх досліджень і публікацій. Значна кількість дослідників, серед яких А. Здравомислов, В. Водзинська, І. Кон, Е. Бєляєв, Г. Саганенко, В. Ядов та ряд інших, окреслюють ціннісні орієнтації як найважливіший компонент у внутрішній структурі особистості, що зафіксований життєвою практикою особистості, всім сполученням iii переживань. Відмежовуючи суттєве і істотне для даної людини від несуттєвого й неістотного, ціннісні орієнтації позначаються в якості здійснювача відбору [6].

У результаті виконання ролі регулятора людської поведінки, ціннісні орієнтації позначаються на всіх життєвих сферах людини, виявляючись зокрема в ії діяльності, перебуваючи при цьому у взаємозв'язку з соціально-психологічними утвореннями особистості. Процес формування їх відбувається під впливом суспільного оточення через особливості тих соціальних груп, до яких належить особистість. Визначення характерних особливостей цінностей призводить до розкриття їх соціального та індивідуального змісту. Оскільки вони історично і культурно зумовлені, то їх зміст розглядається як соціальний, оскільки в них зосереджена життєва практика конкретного суб’ єкта, тоді, у даному випадку, як індивідуальний [7]. 
Регулюючи процес активності людини, виконуючи функцію внутрішньої основи життєвих цілей, ціннісні орієнтації вважаються досить значимим психологічним засобом саморозвитку і особистісного зростання, та дієвим щодо переживання психологічного благополуччя, окреслюючи водночас і напрямок, і практичні прийоми втілення його в життя [5].

Про існування залежності психологічного благополуччя від результатів процесу соціалізації, від відповідності процесу задоволення потреб людини ії суб'єктивним можливостям, зауважує у своєму дослідженні зарубіжний вчений Р.М. Шаміонов, акцентуючи увагу на тому, що сфера потреб тісно пов'язана із сферою самосвідомості [10].

На відповідний зв'язок рівня свідомого життя і смисложиттєвих орієнтацій зі всіма структурними компонентами психологічного благополуччя, вказують результати проведеного у свій час дослідження науковцем П.П. Фесенко. Отримані результати вказують на те, що досліджувані, у яких був виявлений високий рівень психологічного благополуччя різняться 3 досліджуваними, рівень психологічного благополуччя яких 3 низьким показником. Суть розрізнення полягає в тому, що тим, що у досліджуваних 3 високим рівнем психологічного благополуччя рівень свідомості життя і смисложиттєвих орієнтацій значно вищий, зокрема, їх структура значимих термінальних цінностей різниться більш конкретним, свідомо реалізованим характером [1].

У свою чергу, науковець О.С. Ширяєва, здійснюючи своє дослідження в контексті співвідношення психологічного благополуччя із ціннісними орієнтаціями, визначає: афективний, метапотребний, світоглядний, інтрарефлексивний та інтеррефлексивний компоненти з характерними траєкторіями свого вираження. Зокрема, відповідний баланс позитивних і негативних переживань являє собою афективний компонент, виражаючись у суб'єктивних відчуттях щастя, у оптимістичності й загальній задоволеності життям, у емоційному благополуччі та у відсутності вираженої тривожності і симптомів депресії. Наступний компонент розкривається через наявність мети у житті та власних переконань, які надають життю відповідного сенсового змісту - це метапотребний. У свою чергу, компонент світоглядний своїми характеристиками підкреслює наявність незалежності цінностей i поведінки людини від зовнішніх впливів соціуму, спрямованості у неї до творчості, самореалізаційної задоволеності. Прийняття своєї особистості, позитивна оцінка себе і свого життя в цілому, усвідомлення і прийняття не тільки своїх позитивних якостей, але і своїх недоліків, внутрішній контроль, розвинене самопізнання, здатність діяти на основі самосвідомості і внутрішніх цінностей включає в себе інтрарефлексивний компонент. У вираженні психологічного благополуччя інтеррефлексивний його компонент О.С. Ширяєва охарактеризовує наявністю компетентності й гармонійності у стосунках із зовнішнім світом, усвідомлення людиною самої себе в контексті взаємин з іншими, суспільством та природою зокрема [11].

Відповідне бачення психологічного благополуччя в системі активності особистості висловлює дослідник І. Джідарьян, звертаючи увагу на те, що психологічне благополуччя у визначеній системі виступає кільцем зворотного зв'язку, впливаючи на життя людей в залежності від здійсненого вибору ними життєвих стратегій. У ході проведеного дослідження, на основі виявлених параметрів зв'язку психологічного благополуччя i ціннісно-смислових орієнтацій, автором було визначено їх прояв в комплексі iз відповідними факторами, а саме: відхід від проблем, внутрішні особистісні зміни, ціннісно-смислові орієнтації і проблемно-орієнтована поведінка [3].

На думку російського психолога Н.Р. Саліхової, регуляційний механізм життєдіяльності особистості визначає психологічне благополуччя і рівень задоволеності іiі власним життям. Психологічне благополуччя розглядається вченою в будові ланцюга зворотного зв'язку. У зміст останнього входять переживання, які об'єднують в собі оцінки результативності суб'єкта на різних рівнях організації життєдіяльності, вміщуючи у його свідомість загальний підсумок свого життя щодо відповідності його основосновним смисловим орієнтирам. У випадку, коли переживання суб'єкта характеризується 
негативним характерним забарвленням, тоді застосовується вплив корекційного характеру, на основі побудови людиною нових за змістом життєвих цілей чи віднаходження інших способів для досягнення, але вже більш ефективного, за наявності відповідних цілей. Таким чином, авторська концепція ціннісно-смислової регуляції життєдіяльності суб'єкта Н.Р. Саліхової об'єднує в собі усвідомлення людиною процесу реалізації життєво значимих для неї цінностей, переживання нею психологічного благополуччя i визначення й планування подальших життєвих завдань і стратегій [9].

Даний аспект досліджуваної проблеми знаходить своє вираження і в дослідженнях англійського вченого I. Бонівелля, який наголошує на тому, що ціннісні орієнтації, відіграючи регулятивну роль в поведінці особистості, пов'язані з ії уявленнями щодо характеристики життя (погане, добре). Співставляючи вище назване з рефлексуючими компонентами власної життєдіяльності, особистість отримує загальне уявлення про якість свого життя, що сприяє виникненню у неї переживання психологічного благополуччя [2].

Говорити про переживання психологічного благополуччя / неблагополуччя та його специфіку можливо, розкриваючи особливості ієрархічної будови ціннісних орієнтацій суб'єкта. Дане переживання, співвідносячись по-різному 3 конкретною реальністю життєдіяльності людини, може відповідати або не відповідати очікуванням референтних груп. Оцінювання особистістю власних умов життєздійснення i, зокрема, себе самої, визначається на основі соціальних патернів. Останні закладають умови для внутрішніх оцінок, відображаючи симбіоз зовнішніх і внутрішніх умов розвитку особистості.

Постановка завдання. Мета дослідження полягає у виявленні впливу ціннісних орієнтацій на формування уявлень про психологічне благополуччя у студентської молоді.

Виклад основного матеріалу дослідження. У контексті нашого теоретико-методологічного підходу щодо вивчення означеної проблеми, нами було визначено, що психологічне благополуччя особистості вибудовується на основі співвідношення систем ціннісних орієнтацій і оцінки досягнень в тих чи інших сферах пї життєдіяльності, впливаючи тим самим на появу відповідного рівня ставлення до цих сфер, до себе як особистості і своїх цінностей, ролі, установки.

Аналіз зарубіжних та вітчизняних наукових доробків з проблеми вивчення ціннісних устроїв психологічного благополуччя особистості свідчить, що дослідження особистості та ії внутрішнього світу, ціннісних орієнтацій і благополуччя $є$ актуальним на даний час в площині сучасної психологічної науки, але на жаль, не дуже вираженою у наукових доробках вітчизняної психології, зокрема у методологічних і системних підходах. Даний факт підкреслює теоретичну і практичну необхідність проведеного нами дослідження.

Вдаючись до визначення ціннісних орієнтирів життя особистості як значимих елементів системи іiі соціальних взаємин, котрі окреслюють загальні способи іiі поводження у соціумі, іï ставлення до світу, до людей і до самої себе, ставимо акцент на тому, що зазначені устрої (ціннісні орієнтаціï), наповнюючи зміст i, надаючи напрямок особистісним функціям, позиціям, поведінці, поступкам особистості, являються необхідною умовою переживання iї психологічного благополуччя. Виражаючи внутрішній фундамент взаємин особистості з реальною дійсністю, система ціннісних орієнтацій, утворюючись у відповідних соціально-психологічних умовах (конкретних ситуаціях), визначає іï поведінку. Як опорна проекція багатовимірного світу особистості, ціннісні орієнтації визначають собою суб'єктивний напрямок пошуку щастя та якісно-своєрідні особливості, що стосуються стану психологічного благополуччя особистості.

Таким чином, можна вважати, що ціннісні орієнтації є узагальненим показником окрім спрямованості й потреб особистості, іiі соціальної позиції, рівня духовного розвитку, ще й загального рівня іiї психологічного благополуччя.

У становленні психологічно утвореної особистості психологічне благополуччя 
виконує виняткове призначення. Період навчання у вищій школі припадає на такий віковий етап розвитку людини, як юнацький, завдання якого визначаються розширенням розуміння власної ідентичності, формування почуття дорослості, виникненням відповідальності за власні дії, професійне становлення, заснування поглибленої орієнтації у взаєминах і нормах соціальної дійсності. Тріумфальність проходження етапу юності як відповідного періоду розвитку особистості тісно пов'язана з психологічним благополуччям. Психологічне благополуччя присутнє у кожної людини як певне утворення постійного характеру, але параметри його розвитку різні. Саме цим визначається своєрідна необхідність його дослідження у студентської молоді для виявлення способів поліпшення особистісного розвитку майбутніх фахівців.

Наше дослідження проходило на базі ДВНЗ "Прикарпатський національний університет імені Василя Стефаника” і було побудоване для підтвердження або ж спростування висунутого нами припущення про те, що існує статистичний взаємозв'язок між психологічним благополуччям та ціннісними орієнтаціями у студентської молоді. У дослідженні взяли участь 78 осіб (віком 18-20 років), зокрема, студенти I-II курсів, майбутні фахівці системи “людина-людина" (спеціальностей “Психологія”, “Початкова освіта").

Реалізація емпіричного дослідження здійснювалась на основі підібраного діагностичного інструментарію: спостереження, бесіда, фокус-інтерв'ю, опитування, контент-аналіз, тестування за допомогою психодіагностичних методик (“Шкали психологічного благополуччя К. Риф”, методика “Ціннісні орієнтації” М. Рокича), статистичні методи (кореляційний аналіз - числове співвідношення двох різних змінних). Для визначення саме цього діагностичного інструменту слугувало положення про те, що система ціннісних орієнтацій окреслює змістовну сторону спрямованості особистості, складаючи фундаментальні засади іiі взаємин з оточуючим світом, відповідного ставлення до цього зовнішнього середовища, до людського оточення навколо себе, до себе самої, зокрема, базис світогляду і життєвої мотиваційної активності, особливі підвалини життєвої концепції, виливаючись у власну життєву філософію. Всі розрахунки проводилися за допомогою методики визначення середньоарифметичного значення математичної обробки матеріалів дослідження.

Результати дослідження. Для оцінки актуального (суттєво значимого для розвитку) рівня психологічного благополуччя ми обрали опитувальник

К. Риф “Шкали психологічного благополуччя” в адаптації С.В. Карсканової, переслідуючи мету визначити рівень сформованості психологічного благополуччя у студентів, його загальні параметри у визначеної категорії досліджуваних [4].

Процентне співвідношення результатів ми продемонстрували у вигляді діаграми:

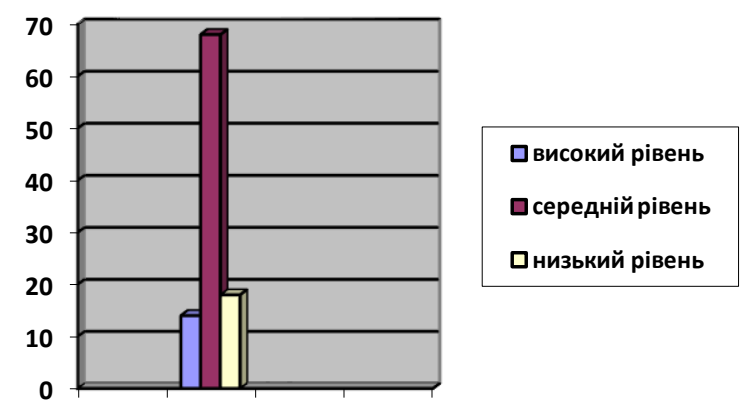

Отримані дані вказують, що у переважній більшості респондентів (69\%) рівень психологічного благополуччя перебуває на середньому рівні визначеної норми. На основі отриманих результатів нами були сформовані дві вибірки з крайніми типами пси- 
хологічного благополуччя: вибірка “благополучні” 3 високим показником рівня психологічного благополуччя та вибірка “неблагополучні” з низьким показником його рівня.

Для глибшого аналізу своєрідності у розумінні структурних компонентів психологічного благополуччя ми вдалися до застосування такого методу як інтерв'ю, виявивши у підсумку, глибинність та багатогранність структурних компонентів психологічного благополуччя у розумінні досліджуваних студентів. На даному етапі нашого дослідження прийшли до висновку, що уявлення сучасної студентської молоді про психологічне благополуччя, його параметрів, характеризуються широкою варіативністю. Остання демонструється як щодо розуміння прояву відчуття задоволення у житті (стану щастя як від сильного, але короткотривалого емоційного піднесення до стану гармонії та спокою), так і щодо його природи (від суб'єктивного “щастя у кожного своє” до об'єктивного “є певний ідеал”, до якого треба застосовувати розуміння тих чи інших фактів), так і на рівні позицій (інфантильне світосприйняття одних студентів контрастує з відповідальною позицією інших).

Проте, незважаючи на різноманітність існуючих наукових підходів до розуміння характеристик даного відчуття, у процесі здійсненого нами обговорення компонентів психологічного благополуччя за моделлю К. Риф, досліджувані студенти загалом вказали на особисту глибинність та багатогранність їх розуміння, виявляючи тісні зв'язки між компонентами запропонованої моделі, а деякі навіть висловлювали свою погодженість із сучасними науковими підходами до визначення психологічного благополуччя (Т.Д. Шевеленкової, П.П. Фесенко та ін.), розглядаючи його як показник ступеня спрямованості на реалізацію основних компонентів позитивного функціонування та ступеня реалізованості даної спрямованості, яка суб'єктивно виражається у домінуванні позитивного афекту, задоволеності собою та життям [12].

Виходячи із поставлених завдань, наступний етап нашого дослідження ми присвятили вивченню ціннісної сфери у досліджуваних двох вибірок “благополучних" i "неблагополучних" кожної зокрема. Аналіз структури ціннісної сфери досліджуваної студентської молоді в залежності від рівня психологічного благополуччя показав, що:

1) у вибірці “благополучних" студентів мають місце деякі суттєві зміни, що стосуються відносно таких цінностей як “здоров'я”, “матеріального забезпечення (достатку)", особливо “щасливе сімейне життя" та ступеню їх реалізованості. Зокрема, цінності “здоров'я” й “щасливе сімейне життя”, перебуваючи попередньо на вершині ієрархічного ряду, демонструють у відповідях досліджуваних показник з тенденцією до зниження щодо реалізованості їх, переходячи у середину ієрархічного ряду, вказуючи про свою недоступність, нереалізованість для студентів на даному життєвому етапі. Наступна цінність “матеріального забезпечення (достатку)", хоч і перебувала в середині ієрархічного ряду за значимістю, демонструє у відповідях досліджуваних вибірки “благополучних" показник з тенденцісю до зниження щодо іiі реалізованості, переходячи до нижчих показників ієрархічного ряду, вказуючи на ті самі тенденції, що стосуються цінності “здоров'я”. Те саме стосується і цінностей “кохання”, “щасливе сімейне життя”, та цінностей соціальної взаємодії, зокрема, такої як “упевненість в собі”. Як бачимо, у діапазоні відповідної напруги перебувають, більшою мірою, такі цінності як “здоров'я”, "матеріальне забезпечення (достаток)", особливо “щасливе сімейне життя";

2) у вибірці "неблагополучних" студентів такі зміни стосуються лише таких пріоритетних цінностей як: “матеріальне забезпечення (достаток)", “щасливе сімейне життя”, “кохання”, “здоров'я” за ступенем реалізованості представлені в даному

випадку низькими рангами (на основі значення середнього показника), вказуючи на свою недоступність, нереалізованість для студентів на даному життєвому етапі. 
Даний факт засвідчує те, що в діапазоні відповідної напруги перебувають сфери взаємовідносин, матеріальних благ й здоров'я. I навпаки, цінності, які характеризуються цілковитою доступністю в реалізації (“пізнання”, “творчість”, “впевненість у собі”, “цікава робота", “свобода"), представлені низькими рангами.

Підсумовуючи, робимо висновок, що на противагу вибірці “благополучних”, для вибірки "неблагополучних" такі сфери як професійно-зорієнтована та ділова, пізнання і особистісного зростання не є значущими. Що стосується решти переліку цінностей, то відмінність в рангах значимих і нереалізованих виявилась невеликою або ж навіть була відсутня.

Під час здійснення кореляційного аналізу даних у двох вибірках, ми отримали структуру взаємозв'язків між корелюючими показниками i, відповідно виявленим набором змінних (тобто цінностей), котрі більшою чи меншою мірою впливають на рівень благополуччя студентської молоді.

Таким чином, у вибірці “благополучних" студентів ми виявили наступні кореляційні залежності: між рівнем психологічного благополуччя та цінностями "здоров'я" $(\mathrm{r}=0,47$ при $\mathrm{p} \leq 0,05)$, “кохання” ( $\mathrm{r}=0,39$ при $\mathrm{p} \leq 0,05)$, “щасливе сімейне життя” ( $\mathrm{r}=0,36$ при $\mathrm{p} \leq 0,05)$, “творчість" ( $\mathrm{r}=0,32$ при $\leq 0,05)$, які, на нашу думку, складають серцевину ціннісної структури досліджуваних студентів. Виявлений зворотній зв'язок між рівнем психологічного благополуччя та життєвих цінностей стосується таких цінностей “добрі і вірні друзі" (r=-0,37 при $\mathrm{p} \leq 0,05)$.

Що стосується вибірки “неблагополучних" студентів, то ціннісну структуру мали б утворювати вибрані ними життєві цінності як: "матеріально забезпечене життя”, "краса природи і мистецтва", “наявність хороших і вірних друзів", “активне, діяльне життя”, “щасливе сімейне життя”, “кохання”, “здоров’я”. На основі кореляційного аналізу у даній вибірці студентів встановлено наступні кореляційні зв'язки: між рівнем психологічного благополуччя та цінностями "матеріальне забезпечене життя" ( $\mathrm{r}=0,48$ при $\mathrm{p} \leq 0,05)$, “краса природи і мистецтва" ( $\mathrm{r}=0,35$ при $\mathrm{p} \leq 0,05)$, “наявність хороших $\mathrm{i}$ вірних друзів" ( $\mathrm{r}=0,43$ при $\mathrm{p} \leq 0,05)$. Зворотній зв'язок виявлений між рівнем психологічного благополуччя та життєвих цінностей як “активне, діяльне життя" (r=-0,39 при $\mathrm{p} \leq 0,05)$, “щасливе сімейне життя” ( $\mathrm{r}=-0,34$ при $\mathrm{p} \leq 0,05)$. На основі порівняльного аналізу наданих студентами переваг серед інтегральних цінностей, судячи з результатів, можна зробити висновок про спрямованість та ступінь активності особистості досліджуваних в тих чи інших сферах життєдіяльності відповідно до виявленого у них рівня психологічного благополуччя.

Отож, спрямованість у вибірці “благополучних” студентів (з високим рівнем психологічного благополуччя) визначається критеріями до активності в соціумі, саморозвитку, духовно-моральною задоволеністю, креативністю, а тому є моральноділовою, яка здатна до реалізації у всіх сферах життєдіяльності. Іншою є спрямованість у вибірці “неблагополучних" студентів (з низьким рівнем психологічного благополуччям), яка характеризується направленістю на авторитетність, досягнення, відповідно-високий рівень матеріального забезпечення, збереження індивідуальності, відзначаючись як егоїстично-престижною. 
Висновки 3 проведеного дослідження. Таким чином, проведене теоретико-емпіричне дослідження підтверджує нашу думку про те, що ціннісні орієнтації є визначальними у поведінці й діяльності людини, детермінуючи рівень їі психологічного благополуччя. Як досить складне інтегральне соціально-психологічне утворення, психологічне благополуччя наповнене власними структурними компонентами, формується в системі реальних стосунків особистості з об'єктами оточуючої дійсності, в процесі соціально-психологічної діяльності, вибудовуючись на основі співвідношення систем ціннісних орієнтацій і оцінки досягнень в тих чи інших сферах життєдіяльності особистості, впливаючи тим самим на появу відповідного рівня ставлення до цих сфер, до себе як особистості і своїх цінностей, рольових функцій.

1. Бессонова Ю. В. О структуре психологического благополуччя. Психологическое благополучие личности в современном образовательном пространстве. Екатеринбург : Изд-во Урал. гос. пед. ун-т., 2013. С. 30-35.

2. Бонивелл И. Ключи к благополучию: Что может позитивная психология / пер. с англ. М. Бабичевой. Москва : Время, 2009. 192 с.

3. Джидарьян И. А. Проблема общей удовлетворенностью жизнью: теоретическое и эмпирическое исследование. Сознание личности в кризисном обществе. Москва, 2009. С. 78-94.

4. Карсканова С. В. “Шкали психологічного благополуччя" К. Риф: процес та результати адаптації. Практична психологія та соиіальна робота. 2011. № 1. С. 1-10.

5. Моральные ценности и личность / под ред. А. И. Титаренко, В. О. Николаичева. Москва : Изд-во МГУ, 1994. $176 \mathrm{c}$.

6. Павліченко А. А. Ціннісні орієнтації у системі становлення особистості. Психологія і суспільство. 2005. № 4. C. $98-120$.

7. Риккерт Г. О системе ценностей. Москва : Логос, 1994. 182 с.

8. Рокич М. Природа человеческих ценностей. Москва ; Нью-Йорк, 1973. 276 с.

9. Салихова Н. Р. Ценностно-смысловая регуляция жизнедеятельности субъекта : автореф. дис. ... д-ра психол. наук. Казань, 2011. 45 c.

10. Шамионов Р. М. Психология субъективного благополучия личности. Саратов, 2004. 174 с.

11. Ширяева О. С. Психологическое благополучие личности в экстремальных условиях жизнедеятельности : автореф. дис. ... канд. психол. наук. Хабаровск, 2008. С. 9-10.

12. Шевеленкова Т. Д., Фесенко П. П. Психологическое благополучие личности (обзор основных концепций и методик исследования). Психологическая диагностика. 2005. № 3. С. 95-129.

Фесенко П. П. Осмысленность жизни и психологическое благополучие личности : автореф. дис. ... канд. психол. наук. Москва : РГГУ, 2005. 20 с. 